\title{
Peningkatan keterampilan sosial melalui permainan gobak sodor
}

\author{
S. Sudarto \\ Program Studi Pendidikan Anak Usia Dini, Sekolah Tinggi Keguruan dan Ilmu Pendidikan \\ Persada Khatulistiwa Sintang. Jl. Pertamina Sengkuang, Km. 4, Sintang, Indonesia \\ *Corresponding Author. Email: sudarto_niarto@yahoo.co.id \\ Received: 11 August 2016; Revised: 30 October 2017; Accepted: 4 October 2018
}

\begin{abstract}
Abstrak
Penelitian ini bertujuan untuk meningkatkan keterampilan sosial melalui permainan gobak sodor. Penelitian ini merupakan penelitian tindakan kelas yang dilakukan dalam dua siklus. Subjek penelitian ini adalah anak kelompok B TK Panca Setya Kabupaten Sintang yang berjumlah 21 anak. Pengumpulan data dilakukan dengan teknik observasi, wawancara, dan dokumentasi. Analisis data menggunakan teknik deskriptif. Hasil penelitian ini menunjukkan bahwa permainan gobak sodor dapat meningkatkan keterampilan sosial pada anak kelompok B TK Panca Setya Kabupaten Sintang. Hasil ini ditunjukkan dengan hasil peningkatan keterampilan sosial pratindakan bahwa dari 21 anak, 3 anak (14,28\%) pada kategori sangat baik. Hasil siklus 1 keterampilan sosial anak meningkat menjadi 10 anak $(47,61 \%)$ pada kategori baik. Hasil siklus 1 ke siklus 2 mengalami peningkatan keterampilan sosial pada kategori sangat baik menjadi 20 anak $(90,47 \%)$.

Kata Kunci: keterampilan sosial, permainan, gobak sodor
\end{abstract}

\section{Eliciting social skills through gobag sodor game}

\begin{abstract}
The research aimed at eliciting the children's social skills through gobag sodor game. The study was a classroom action research that consisted of two cycles. The subjects in the study were the students from Group B of Panca Setya Kindergarten the Regency of Sintang and the number of the subjects was 21 children. The data were gathered through observation, interview, and documentation and were analysed using the descriptive technique. The results of the study show that the gobag sodor game is able to elicit the children's social skill in Group B of Panca Setya Kindergarten in the Regency of Sintang. These results are confirmed by the following findings in terms of social skills. In the pre-action cycle, from 21 subjects 3 subjects 914.28\%) belong to very good category. Then, the results of the first cycle show that from 21 subjects 10 subjects (47.61\%) belong to good category. Last but not the least, from the first cycle to the second cycle it is found that 20 subjects ( $90.47 \%)$ belong to the very good category.
\end{abstract}

Keywords: social skill, game, gobak sodor

How to Cite: Sudarto, S. (2018). Peningkatan keterampilan sosial melalui permainan gobak sodor. JPPM (Jurnal Pendidikan dan Pemberdayaan Masyarakat), 5(1), 85-95.

doi:http://dx.doi.org/10.21831/jppm.v5i1.10374

http://dx.doi.org/10.21831/jppm.v5i1.10374

\section{PENDAHULUAN}

Pendidikan Taman Kanak-Kanak (TK) merupakan bentuk pendidikan untuk rentang usia empat sampai dengan enam tahun. Pendidikan TK bukan pendidikan yang diwajibkan, namun sangat penting bagi kehidupan manusia di masa mendatang. Tingkat pencapaian perkembangan sosial emosional anak usia 5-6 tahun meliputi: bersikap kooperatif dengan teman, menunjukkan sikap 
toleran, mengekspresikan emosi yang sesuai dengan kondisi yang ada (senang-sedih antusias), mengenal tata krama dan sopan santun sesuai dengan nilai sosial budaya setempat, memahami peraturan dan disiplin, menunjukkan rasa empati, memiliki sikap gigih (tidak mudah menyerah), bangga terhadap hasil karya sendiri, dan menghargai keunggulan orang lain (Permendiknas No. 58 Tahun 2009).

Pentingnya siswa menguasai keterampilan sosial tidak diikuti dengan penyusunan program pendidikan yang dapat mengembangkan hal tersebut. Program pendidikan hendaknya tidak hanya berbasis pada penguasaan akademik. Sebab dewasa ini, pelaksanaan pendidikan bagi anak pada kelas awal sekolah dasar masih banyak terjebak dalam formalitas. Pengajaran pengetahuan tidak mantap, bersifat hafalan dan tidak memberi kesempatan bagi anak untuk mendapat pelajaran sambil bermain. Padahal bermain bagi anak merupakan kebutuhan mutlak sesuai dengan karakteristik perkembangannya. Anak menjadi tidak memperoleh keterampilan mental yang diperlukan pada taraf pengetahuan yang lebih tinggi.

Berkaitan dengan keterampilan sosial yang perlu dikembangkan pada anak TK, muncul permasalahan yang berkenaan dengan hal ini, di antaranya anak mengalami kesulitan dalam menyesuaikan diri dengan lingkungan sekolah yang baru dimasukinya, khususnya untuk anak kelompok B, seperti yang terjadi di TK Panca Setya Kabupaten Sintang. Tidak dikuasainya keterampilan sosial pada anak akan mempengaruhi proses belajar mengajar serta iklim yang ada di suatu kelas (psychological athmosphere). Banyak anak yang tidak pernah belajar tentang sikap apa yang dapat diterima di lingkungannya. Barangkali mereka juga tidak diarahkan baik di rumah maupun di sekolah untuk dapat menguasai perilaku sosial tersebut. Mereka juga tidak memiliki model yang dapat dijadikan contoh dalam membina kehidupan sosialnya, sehingga kerap memunculkan permasalahan dalam bersosialisasi. Anak-anak yang kurang memiliki keterampilan sosial sangat memungkinkan untuk ditolak oleh rekan yang lain.
Anak yang tidak mampu bekerja sama, tidak mampu menyesuaikan diri, tidak mampu berinteraksi dengan baik, tidak dapat mengontrol diri, tidak mampu berempati, tidak mampu menaati aturan serta tidak mampu menghargai orang lain akan sangat mempengaruhi perkembangan anak lainnya. Sebaliknya, terbinanya keterampilan sosial pada diri anak akan memunculkan penerimaan dari teman sebaya, penerimaan dari guru, dan sukses dalam belajarnya.

Stimulus yang diberikan kepada anak usia dini tentunya harus sesuai dengan perkembangan mereka. Tahap perkembangan ini dapat ditinjau dari berbagai aspek seperti kognitif, bahasa, emosi, sosial, dan fisik. Proses penyampaiannya pun harus sesuai dengan dunia anak, yaitu dengan bermain. Sebab, bermain merupakan sarana belajar bagi mereka. Bermain merupakan proses mempersiapkan diri untuk memasuki dunia selanjutnya.

Bermain merupakan cara bagi anak untuk memperoleh pengetahuan tentang segala sesuatu. Bermain akan menumbuhkan anak untuk melakukan eksplorasi, melatih pertumbuhan fisik serta imajinasi, memberikan peluang yang luas untuk berinteraksi dengan orang dewasa dan teman lainnya, mengembangkan kemampuan berbahasa dan menambah kata-kata, serta membuat belajar yang dilakukan sebagai belajar yang sangat menyenangkan. Model bermain peran efektif untuk dijadikan model bimbingan dalam mengembangkan keterampilan sosial anak berkemampuan unggul (Ahman, 1998, p.12).

Dalam dimensi proses, bermain peran telah membantu anak memperoleh pengalaman berharga melalui aktivitas interaksional dengan teman-temannya. Anak belajar memberi masukan atas peran orang lain, dan menerima masukan dari orang lain. Di samping dapat menimba pengalaman mengenai cara-cara menghadapi masalah, melalui bermain peran, para anak dapat melatih diri menerapkan prinsip-prinsip demokrasi.

Aktivitas bermain yang dilakukan oleh anak-anak telah menstimulasi munculnya beragam permainan yang diperuntukkan bagi mereka. Secara umum kita dapat mengklasifikasikanya ke dalam dua jenis yaitu permainan modern dan permainan tradisional. 


\section{JPPM (Jurnal Pendidikan dan Pemberdayaan Masyarakat), 5 (1), 2018 - 87}

\section{S. Sudarto}

Fenomena efek negatif permainan modern telah mengarahkan suatu pemikiran untuk kembali lagi ke dasar (back to basic) untuk lebih memperkenalkan anak-anak usia dini pada jenis permainan tradisional.

Permainan tradisional memberikan alternatif yang kaya dengan nilai budaya (culture), dan bahkan mungkin saat ini sudah hampir punah jika tidak dipelihara dan dikembangkan. Permainan tradisional, dewasa ini telah menjadi barang yang sangat langka. Padahal jika kita analisis terdapat sejumlah permainan tradisional yang memberikan peran terhadap pengembangan potensi anak seperti perkembangan motorik kasar, halus, sosial, kognitif serta aspek perkembangan lainnya. Nilai kearifan lokal yang berupa rasa syukur, tidak sombong, tidak keras kepala, kebersamaan, berpikir kritis, cermat, legowo, silaturahmi, kesabaran, ketelitian, kreativitas, produk lokal, tata karma tersebut terimplementasi melalui lagu tradisional, permainan, lingkungan sekitar, makanan, pakaian, serta bahasa jawa (Wahyuningsih \& Suyanto, 2015, p.14).

Badegruber (2008, p.1) mengatakan bahwa bermain adalah tentang suka-cita melakukan sesuatu. Dalam bermain, mendapatkan hidup dan berjuang untuk bertahan hidup mengambil kembali kursi pada kenyataannya, hasil apapun adalah hanya kurang penting.

Permainan selalu menggairahkan anakanak dan memuncak ketika dimainkan pada hari khusus (Lewis \& Bedson, 2010, 8). Badegruber (2008, p.1) mengatakan bahwa bermain adalah tentang sukacita melakukan sesuatu. Dalam bermain, mendapatkan hidup dan berjuang untuk bertahan hidup mengambil kembali kursi pada kenyataannya, hasil apapun adalah hanya kurang penting. Plummer (2007, p. 7) mengatakan bahwa: "played as energizers or treats can be exciting and fun and a source of immense pleasure for the players. Occasionally, however, they can also be sheer torture for the quiet child, the childwho has difficulty understanding the rules of games, the child who is already full of pent-up frustration or anxiety, or who fears being 'left out' or losing yet again".

Permainan sebagai dapat menarik dan menyenangkan dan sumber kesenangan luar biasa bagi para pemain (Plummer, 2007). Namun, mereka juga bisa menjadi siksaan belaka bagi ketenangan anak, anak yang memiliki kesulitan untuk memahami aturan permainan, anak yang sudah penuh frustrasi atau kecemasan terpendam, atau yang takut yang 'ditinggalkan' atau kalah lagi.

Lewis \& Bedson (2010, p. 8) mengatakan bahwa permainan makin hampir selalu menggairahkan anak-anak. Proyek ini memuncak pada hari khusus ketika permainan ini dimainkan. Lynch \& Simpson (2010, pp.311) mengatakan bahwa "social skills are behaviors that promote positive interaction with others and the environment. Some of these skills include showing empathy, participation in group activities, generosity, helpfulness, communicating wiyh others, negotiating, and problem solving".

Dowd, \& Tierney (2011, pp.5-6) mengatakan bahwa keterampilan sosial adalah alat yang memungkinkan orang untuk berkomunikasi, belajar, mengajukan pertanyaan, me-minta bantuan, mendapatkan kebutuhan mereka bertemu dengan cara yang tepat, bergaul dengan orang lain, membuat temanteman dan mengembangkan hubungan yang sehat, melindungi diri, dan umumnya dapat berinteraksi dengan siapa pun dan semua orang yang mereka bertemu di perjalanan mereka melalui kehidupan. Koyama (2011, pp.4-5) mengatakan bahwa saat anak mengembangkan kehidupan sosialnya dan mulai berinteraksi dengan anak lain yang seumuran. Mereka dihadapkan pada harapan tambahan sosial dan mulai belajar keterampilan seperti memulai dan mempertahankan interaksi berbagi mainan dan alat permainan serta bermain dengan baik bersama temannya. Wike (2011, pp.14-15) mengatakan bahwa perilaku agresif pada anak usia menempatkan anak pada risiko untuk sejumlah hasil negatif, termasuk rekan-penolakan dan ketidakmampuan sosial, serta kemudian masalah dengan penggunaan narkoba, kekerasan hubungan, kejahatan dan kenakalan. Pembangunan sosial menekankan kebutuhan untuk menetapkan intervensi pencegahan pada anak usia dini dalam rangka untuk mengganggu lintasan perkembangan ke arah lebih lanjut agresi dan kekerasan. 
Matson (2009, p.2) mengatakan bahwa mengidentifikasi tiga jenis yang berhubungan dengan perilaku sosial yaitu rekan penerimaan, perilaku, dan validitas sosial.

Hurlock (1978, p.251) mengatakan bahwa orang yang memiliki keterampilan sosial adalah mereka yang perilakunya mencerminkan keberhasilan di dalam tiga aspek socialisasi. Ketiga aspek sosialisasi yaitu, belajar berperilaku yang dapat diterima secara sosial, memainkan peran sosial yang dapat diterima, dan perkembangan sikap sosial. Keterampilan sosial merupakan keterampilan yang diperoleh melalui proses belajar mengenai cara-cara mengatasi dan melakukan hubungan sosial dengan baik.

Badegruber (2008, p.1) mengatakan bahwa bermain adalah tentang sukacita melakukan sesuatu. Dalam bermain, mendapatkan hidup dan berjuang untuk bertahan hidup mengambil kembali kursi pada Kenyataannya, hasil apapun adalah hanya kurang penting. Spence (2008, pp.8-9) mengatakan bahwa defisit dalam keterampilan sosial dan kompetensi sosial memainkan peran penting dalam pengembangan dan pemeliharaan banyak gangguan emosi dan perilaku masa kanak-kanak dan remaja. Pelatihan keterampilan sosial bertujuan untuk meningkatkan kemampuan untuk melakukan perilaku sosial kunci yang penting dalam mencapai keberhasilan dalam situasi sosial.

Ada enam aspek utama dalam keterampilan sosial pada masa kanak-kanak, yaitu sikap ramah, sikap tidak mementingkan diri sendiri, kemurahan hati, hasrat akan penerimaan sosial, kerjasama, dan persaingan yang baik (Hurlock, 1978, p.262). Peneliti mengambil enam aspek keterampilan sosial berdasarkan permasalahan krusial yang terangkum pada saat observasi awal. Permasalahan krusial tersebut semuanya berhubungan erat dengan proses pembentukan kepribadian sosial serta kemampuan bersosialisasi yang rendah pada diri siswa di TK kelompok B. Pengembangan sejak dini dari enam aspek tersebut akan mampu membentuk siswa yang terampil dalam bersosialisasi dengan teman sebayanya maupun dengan orang lain.

Permainan tradisional diyakini akan memberikan dampak yang lebih baik bagi pengembangan potensi anak, jika permainan modern lebih mengutamakan individualisasi, maka permainan tradisional lebih memberikan kesempatan kepada anak untuk bersosialisasi dan berkerja sama dalam kelompok. Hal ini diperkuat juga oleh Bodrova \& Leong (2003, p.3) mengatakan bahwa "now a days young children spend less time playing with their peers and more time playing alone, graduating frorm educational toys to video and computer game".

Mengeksplorasi dan menggali kekayaan budaya dengan mengumpulkan jenis-jenis permainan tradisonal serta melakukan analisis tentang potensi apa yang bisa dikembangkan pada saat mereka mengikuti permainan tersebut, dan hal ini menjadi suatu tantangan tersendiri bagi peneliti. Contoh di atas (Anyang-anyangan) bahwa merupakan salah satu contoh permainan tradisional. Beberapa di antaranya lagi adalah Gatrik, Sonlah, Beklen, Loncat Tinggi, Galah, UcingUcingan, Hompimpa, Encrak, Sepdur, Sorodot Gaplok, Grandongan, Gagarudaan, Centring, Adu layangan, Batokan, dan Galasin/gobak sodor.

Permainan gobak sodor bersifat kelompok bukanlah individual dan dapat dimainkan oleh anak laki-laki dan anak perempuan. Permainan gobak sodor mengandung unsur-unsur melatih keterampilan, ketangkasan dan kelincahan. Dengan bermain gobak sodor anak banyak melakukan gerakan berputar dan bergerak bebas mengecoh lawan untuk mencapai tujuan pada akhir ke bilik pangkal. Sedangkan kelompok penjaga hanya bergerak lurus seperti tombak dengan mengikuti arah garis bilik untuk menyentuh badan pemeran (Parmadhi, 2005, pp.5-6).

Wawancara yang peneliti lakukan dengan ibu Yupita selaku guru kelompok B TK Panca Setya Kabupaten Sintang, memperoleh beberapa permasalahan yang selama ini dialami guru dalam melaksanakan pembelajaran. Guru menyampaikan permasalahan yang dialami oleh guru seperti (1) anak tidak mempunyai relasi dan sikap negatif terhadap anak lain, (2) mempunyai sikap cenderung senang memilih teman untuk bermain sendiri, (3) tidak mau bekerja sama dengan kelompok, (4) tidak mau bersosialisasi dengan anak lain, (5) keterampilan sosial 
anak masih rendah, (6) anak yang dominan sering mengejek anak yang lemah.

Berdasarkan wawancara dan hasil observasi peneliti di TK Panca Setya Kabupaten Sintang pada hari senin tanggal 2 September 2015 ditemukan bahwa keterampilan sosial masih rendah. Peneliti melihat bahwa ada beberapa anak memilih teman yang akan dijadikan kelompoknya yaitu, anak perempuan memilih teman perempuan dan sebaliknya (antagonisme jenis kelamin), dan ada anak yang tidak mau membantu temannya yang kesulitan memahami materi pelajaran. Begitu pula pada jam istirahat, anak mempunyai kelompok bermainnya sendiri (membuat gang) yang didominasi oleh anak yang dominan di dalam kelasnya, sehingga anak yang lemah cenderung tertindas.

Anak yang dominan sering mengejek anak yang lemah bahkan sampai terjadi kontak fisik. Terbukti dari 21 anak di kelompok B, hanya 5 anak yang sudah mampu bersosialisasi dengan baik dengan teman sebaya. Sedangkan 16 anak masih suka memilih-milih teman dalam bermain atau dalam pemilihan tempat duduk. Anak-anak juga masih suka ramai sendiri ketika guru memberikan pembelajaran

Berdasarkan hal tersebut, penelitian ini untuk mengetahui proses meningkatkan keterampilan sosial melalui permainan gobak sodor anak usia 5-6 tahun di TK Panca Setya Kabupaten Sintang, dan untuk mengetahui hasil peningkatkan keterampilan sosial melalui permainan gobak sodor anak usia 5-6 tahun di TK Panca Setya Kabupaten Sintang.

\section{METODE}

Jenis penelitian ini adalah penelitian tindakan kelas yang dilakukan secara kolaboratif dengan Ibu Yupita guru kelompok B. Penelitian tindakan kelas yang digunakan dalam penelitian ini mengacu pada model Kemmis dan McTaggart (Dwitagama \& Kusuma, 2011, p.21) yang terdiri atas empat komponen, yaitu perencanaan (plan), tindakan (act), pengamatan (observe), dan refleksi (reflect). Dalam tahap perencanaan ini, peneliti menjelaskan tentang apa, mengapa, kapan, di mana, oleh siapa, dan bagaimana tindakan dilakukan. Dalam tahap menyusun rancangan ini, peneliti menentukan titik atau fokus peristiwa yang perlu mendapat perhatian khusus untuk diamati, kemudian membuat sebuah instrumen pengamatan untuk membantu peneliti merekam fakta yang terjadi selama tindakan berlangsung.

Pada tahap ini peneliti merancang tindakan yang akan dilakukan dalam penelitian, di antaranya, (a) mengidentifikasi masalah yang ada di dalam kelas yang akan menjadi topik yang perlu perhatian khusus dan merupakan topik dalam penelitian ini. (b) membuat Rencana Kegiatan Harian $(\mathrm{RKH})$, materi yang diajarkan tentunya sesuai dengan kurikulum yang dituangkan dalam RKH. RKH ini berguna sebagai pedoman guru dalam melakasanakan kegiatan keterampilan sosial. (c) guru mempersiapkan lembar observasi mengenai patisipasi anak. (d) mempersiapkan sarana dan media yang akan digunakan yaitu permainan dan halaman pelaksanaan kegiatan serta sarana pendukung lainnya. (e) mengevaluasi kegiatan, agar dapat mengetahui keadaan anak dan kesulitan dalam kegiatan keterampilan social, (f) materi yang ditekankan pada penelitian ini meliputi kegiatan, yaitu " Permainan Gobak sodor".

Tahap pelaksanaan tindakan ini dilakukan selama pembelajaran berlangsung dengan dibantu guru untuk mengamati keterlibatan atau partisipasi anak saat kegiatan "bermain gobak sodor". Untuk selanjutnya hasil dari kegiatan anak diamati dan dicatat sebagai hasil pengamatan untuk dievaluasi dan direfleksi bersama kolaborator, sehingga dapat menentukan, merencanakan pertemuan berikutnya kearah peningkatan. Pada tahap observasi kegiatan akan dilakukan oleh peneliti dengan guru melakukan observasi terhadap kegiatan pembelajaran di dalam kelas maupun di luar kelas yang telah dilakukan guru dan siswa. Hal-hal yang akan diamati adalah mengenai keterampilan sosial anak, baik dalam berkomunikasi, sikap dan sosialisasi.

Pada tahap refleksi adalah data-data yang sudah diperoleh dari observasi baik sebelum maupun setelah kegiatan tersebut kemudian dicatat, dikumpulkan dan Dianalisis serta didiskusikan bersama kolaborator. Setiap akhir pertemuan dalam setiap siklus peneliti dan kolaborator menganalisis apa 
pelaksanaan tindakan sudah sesuai perencanaan, apakah format observasi perlu ditambah dan sebagainya, sehingga hasil analisis tadi dapat digunakan untuk menentukan langkah selanjutnya. Tujuan dari diskusi tersebut adalah untuk mengevaluasi hasil tindakan, masalah yang muncul dan segala hal yang berkaitan dengan tindakan yang dilakukan. Setelah selesai berdiskusi peneliti mencari jalan keluarnya agar dibuat rencana perbaikan pada tahap kegiatan selanjutnya.

Waktu penelitian dilakukan pada tahun ajaran 2014/2015 pada bulan Oktober sampai dengan bulan November 2015. Penelitian dilakukan di dalam ruangan. Tempat penelitian dilakukan di TK Panca Setya kelompok B. TK Panca Setya ini berada di tengah kota. Alamat lengkap TK Panca Setya, Jalan M. Saad, Kelurahan Tanjungpuri, Kecamatan Sintang, Kabupaten Sintang, Kalimantan Barat.

Subjek penelitian diambil dari peserta didik kelompok B di TK Panca Setya yang berjumlah 21 anak, laki-laki 8 orang dan perempuan 13 orang. Dari jumlah total 21 anak di kelas, sebanyak 16 anak masih memilih-milih teman dalam bermain atau dalam pemilihan tempat duduk. Anak tidak mau bekerjasama dengan kelompok, dan tidak mau bersosialisasi dengan anak lain. Objek dalam penelitian ini adalah keterampilan sosial bermain gobak sodor pada anak. Peneliti memilih kelompok B untuk dijadikan sebagai subjek penelitian ini, karena kelompok B keterampilan sosial masih rendah dalam kegiatan bermain gobak sodor.

Penelitian dilaksanakan berdasarkan tahapan persiklus yaitu tahapan untuk mengetahui perkembangan keterampilan sosial anak sebelum tindakan. Tahapan prasiklus dilaksanakan pada tanggal 26 Oktober sampai tanggal 9 November 2015. Pada siklus I dilaksanakan 3 kali pertemuan. Pelaksanaan siklus ke II juga 3x pertemuan.

Teknik yang digunakan dalam pengumpulan data sebagai berikut: (1) teknik observasi. Teknik observasi diartikan sebagai pengamatan dan pencatatan secara sistematik terhadap gejala yang tampak pada objek penelitian. Dalam penelitian tindakan observasi adalah kegiatan pengamatan (pengam- bilan data) untuk melihat seberapa jauh efek tindakan telah mencapai sasaran.

Teknik ini digunakan untuk mengamati dan menganalisis dalam pelaksanaan permainan gobak sodor. (2) teknik wawancara. Teknik wawancara adalah teknik pengumpulan data yang digunakan peneliti untuk mendapatkan keterangan-keteranga lisan melalui bercakap-cakap dan berhadapan muka dengan orang yang dapat memberikan informasi kepada peneliti. Wawancara ini dilakukan kepada guru kelas.

Kriteria keberhasilan produk keterampilan sosial ini adalah apabila dalam penelitian tindakan kelas ini, semua siswa mencapai kriteria baik yaitu mencapai peningkatan 61$80 \%$ pada indikator sikap ramah, tidak mementingkan diri sendiri, kemurahan hati, hasrat akan penerimaan sosial, kerjasama, dan persaingan baik. Kriteria berupa persentase kesesuaian yaitu: (1) kesesuaian kriteria (\%): 21-40 kurang, (2) kesesuaian kriteria (\%): 41-6o cukup, (3) kesesuaian kriteria (\%): 61-8o baik, (4) kesesuaian kriteria (\%): 81-10o sangat baik.

Analisis data adalah proses penyusunan data kegiatan tindakan agar dapat ditafsirkan secara mendalam. Berikut rumus yang digunakan dalam analisis data dengan teknik deskriptif persentase. $\mathrm{P}=\frac{f}{N} \times 100 \mathrm{~F}=$ frekuensi yang sedang dicari persentasenya $\mathrm{N}=$ Number of Cases (Jumlah Frekuensi) $\mathrm{P}=$ Angka Persentase.

\section{HASIL DAN PEMBAHASAN}

Peneliti melakukan kegiatan pratindakan sebelum memberikan tindakan kepada siswa pada hari Senin 26 Oktober 2015. Kegiatan pratindakan digunakan sebagai langkah awal untuk mengamati permasalahan yang ada pada anak. Adapun hasil observasi awal baik dalam proses pembelajaran maupun di luar kelas anak kelompok B.

Hasil yang diperoleh melalui observasi pada anak kelompok B TK Panca Setya Kabupaten Sintang mengenai keterampilan sosial pada enam aspek masih dalam kategori rendah atau kurang. Adapun secara detail hasil observasi adalah sebagai berikut. (1) selama proses pembelajaran beberapa anak kurang berkonsentrasi. (2) anak memilih 


\section{JPPM (Jurnal Pendidikan dan Pemberdayaan Masyarakat), 5 (1), 2018 - 91}

\section{S. Sudarto}

teman dalam satu kelompok yaitu anak perempuan memilih teman perempuan semua dalam satu kelompoknya dan sebaliknya. (3) anak yang dominan sering mengejek atau menggertak anak yang lemah. (4) beberapa anak berbicara dengan temannya saat pembelajaran berlangsung, dan (5) anak mempunyai kelompok bermainnya sendiri/ membuat gang yang didominasi oleh anak yang dominan dalam kelasnya, sehingga siswa yang lemah cenderung tertindas.

Berdasarkan hasil observasi tentang keterampilan sosial anak sebelum dilakukan tindakan pada Tabel 1, maka dapat diketahui beberapa anak masih menunjukkan bahwa keterampilan sosial anak masih rendah. Hal ini dapat dilihat pada Tabel 1, anak yang sangat baik berjumlah 3 anak (14,28\%), baik 8 anak (38,09\%) cukup 9 anak (42,85\%) dan rendah ranak $(4,76 \%)$.

Tabel 1. Persentase Observasi Keterampilan Sosial Anak pada Tahap Pratindakan

\begin{tabular}{crlcc}
\hline No. & Skor & Kategori & $\begin{array}{c}\text { Jumlah } \\
\text { siswa }\end{array}$ & Persentase \\
\hline 1. & 4 & Sangat baik & 3 & $14,28 \%$ \\
2. & 3 & Baik & 8 & $38,09 \%$ \\
3. & 2 & Cukup & 9 & $42,85 \%$ \\
4. & 1 & Rendah & 1 & $4,76 \%$ \\
\multicolumn{2}{l}{ Jumlah } & & 21 & \\
\hline
\end{tabular}

Pelaksanaan penelitian Siklus I dilakukan pada tanggal 28 Oktober 2015 sampai 30 Oktober 2015. Siklus ini dilaksanakan selama 3 kali pertemuan 2 x 30 menit. Standar kompetensi yang dilaksanakan pada siklus ini adalah mempraktikkan gerak dasar ke dalam permainan sederhana serta nilai-nilai yang terkandung di dalamnya.

Hasil penelitian pada siklus I pertemuan I menunjukkan adanya peningkatan keterampilan sosial siswa dalam aspek yang ada dalam instrumen penelitian.

Tabel 2. Persentase Observasi Keterampilan Sosial Anak Siklus I Pertemuan I

\begin{tabular}{crlcc}
\hline No. & Skor & Kategori & $\begin{array}{c}\text { Jumlah } \\
\text { siswa }\end{array}$ & Persentase \\
\hline 1. & 4 & Sangat baik & 3 & $14,28 \%$ \\
2. & 3 & Baik & 8 & $38,09 \%$ \\
3. & 2 & Cukup & 9 & $42,85 \%$ \\
4. & 1 & Rendah & 1 & $4,76 \%$ \\
\multicolumn{2}{c}{ Jumlah } & & 21 & \\
\hline
\end{tabular}

Berdasarkan Tabel 2 hasil observasi dapat dilihat bahwa terdapat peningkatan lagi dalam keterampilan sosial anak. Anak yang sangat baik berjumlah 3 anak (14,28\%), baik 8 anak (38,09\%) cukup 9 anak (42,85\%) dan rendah $1(4,76 \%)$. Hasil penelitian pada siklus I pertemuan II menunjukkan adanya peningkatan kemampuan keterampilan sosial anak dalam yang ada dalam intrumen penelitian.

Tabel 3. Persentase Observasi Keterampilan Sosial Anak Siklus I Pertemuan II

\begin{tabular}{cclcc}
\hline No. & Skor & Kategori & $\begin{array}{c}\text { Jumlah } \\
\text { siswa }\end{array}$ & Persentase \\
\hline 1. & 4 & Sangat baik & 3 & $14,28 \%$ \\
2. & 3 & Baik & 9 & $42,85 \%$ \\
3. & 2 & Cukup & 8 & $38,09 \%$ \\
4. & 1 & Rendah & 1 & $4,76 \%$ \\
Jumlah & & & 21 & \\
\hline
\end{tabular}

Berdasarkan Tabel 3 hasil observasi dapat dilihat bahwa terdapat peningkatan lagi dalam keterampilan sosial anak. Anak yang sangat baik berjumlah 3 anak $(14,28 \%)$, baik 9 anak (42,85\%), cukup 8 anak (38,09\%), dan rendah 1 anak $(4,76 \%)$.

Hasil penelitian pada siklus I pertemuan III menunjukkan ada peningkatan keterampilan sosial siswa dalam aspek yang ada dalam instrumen penelitian. Pada pertemuan kedua ini kegiatannya tidak jauh berbeda dengan kegiatan pertemuan sebelumnya.

Tabel 4. Persentase Observasi Keterampilan Sosial Anak Siklus I Pertemuan III

\begin{tabular}{cclcl}
\hline No. & Skor & Kategori & $\begin{array}{c}\text { Jumlah } \\
\text { siswa }\end{array}$ & Persentase \\
\hline 1. & 4 & Sangat baik & 10 & $47,6 \%$ \\
2. & 3 & Baik & 8 & $38,0 \%$ \\
3. & 2 & Cukup & $\mathbf{2}$ & $9,52 \%$ \\
4. & 1 & Rendah & $\mathbf{1}$ & $4,76 \%$ \\
Jumlah & & & $\mathbf{2 1}$ & \\
\hline
\end{tabular}

Berdasarkan Tabel 4 hasil observasi dapat dilihat bahwa terdapat peningkatan lagi dalam keterampilan sosial anak. Anak yang sangat baik berjumlah 10 anak $(47,61 \%)$, baik 8 anak (38,09\%) cukup 2 anak (9,52\%) dan rendah $1(4,76 \%)$. Dari data hasil observasi keterampilan sosial anak pada siklus I pertemuan ke III.

Penelitian tindakan Siklus II sebanyak tiga kali pertemuan $(2 \times 30)$ dengan tema 
diriku/tubuhku. Pertemuan pertama dilaksanakan pada tangggal 2 November 2015. Siklus ini dilaksanakan selama tiga kali pertemuan (2 x 30 menit). Standar kompetensi yang dilaksanakan pada siklus ini adalah mempraktekkan gerak dasar ke dalam permainan sederhana dan olahraga serta nilai yang terkandung di dalamnya. Berikut ini penjelasan pelaksanaan siklus II.

Bersamaan dengan tahap tindakan, observer melakukan observasi. Kegiatan observasi dilakukan untuk mengamati keterampilan sosial siswa setelah melakukan permainan gobak sodor. Observasi pada siklus II pertemuan I dilakukan secara berkolaborasi dengan guru kelas. Kegiatan yang diamati meliputi, kerjasama, persaingan yang baik, kemurahan hati, hasrat akan penerimaan sosial, sikap ramah, dan sikap tidak mementingkan diri sendiri. Hasil penelitian pada siklus II pertemuan I menunjukkan adanya peningkatan keterampilan sosial siswa dalam aspek yang ada dalam intrumen penelitian.

Tabel 5. Persentase Hasil Observasi Keterampilan Sosial Anak Siklus II Pertemuan I

\begin{tabular}{|cclcc|}
\hline No. & Skor & Kategori & $\begin{array}{c}\text { Jumlah } \\
\text { siswa }\end{array}$ & Persentase \\
\hline 1. & 4 & Sangat baik & 10 & $1 \%$ \\
2. & 3 & Baik & 10 & $47,61 \%$ \\
3. & 2 & Cukup & 1 & $4,76 \%$ \\
4. & 1 & Rendah & o & 0\% \\
Jumlah & & & 21 & \\
\hline
\end{tabular}

Berdasarkan Tabel 5 dapat dilihat bahwa terjadi peningkatan lagi dalam keterampialn sosial anak. Untuk anak yang sangat baik berjumlah 10 anak $(47,61 \%)$, baik berjumlah 10 anak $(47,61 \%)$, cukup berjumlah 1 anak $(4,76 \%)$ dan anak yang rendah o (o\%).

Hasil penelitian pada siklus II pertemuan II menunjukkan bahwa adanya peningkat- an keterampilan sosial anak dalam aspek yang ada dalam instrumen penelitian.

Berdasarkan Tabel 6 dapat dilihat bahwa terjadi peningkatan lagi dalam keterampilan sosial anak. Untuk anak yang sangat baik berjumlah 14 anak $(66,66 \%)$, baik berjumlah 6 anak $(28,57 \%)$, cukup berjumlah 1 anak $(4,76 \%)$ dan anak yang rendah o (o\%).

Tabel 6. Persentase Hasil Observasi Keterampilan Sosial Anak pada Siklus II Pertemuan II

\begin{tabular}{|cclcl|}
\hline No. & Skor & Kategori & $\begin{array}{c}\text { Jumlah } \\
\text { siswa }\end{array}$ & Persentase \\
\hline 1. & 4 & Sangat baik & 14 & $66,66 \%$ \\
2. & 3 & Baik & 6 & $28,57 \%$ \\
3. & 2 & Cukup & 1 & $4,76 \%$ \\
4. & 1 & Rendah & o & 0\% \\
Jumlah & & 21 & \\
\hline
\end{tabular}

Hasil penelitian pada siklus II pertemuan III menunjukkan adanya peningkatan keterampilan sosial siswa dalam aspek yang ada dalam intrumen penelitian.

Tabel 7. Persentase Hasil Observasi Keterampilan Sosial Anak Siklus II Pertemuan III

\begin{tabular}{lrlcc}
\hline No. & Skor & Kategori & $\begin{array}{c}\text { Jumlah } \\
\text { siswa }\end{array}$ & Persentase \\
\hline 1. & 4 & Sangat baik & 19 & $90,47 \%$ \\
2. & 3 & Baik & 1 & $4,76 \%$ \\
3. & 2 & Cukup & 1 & $4,76 \%$ \\
4. & 1 & Rendah & o & 0\% \\
\multicolumn{2}{l}{ Jumlah } & & 21 & \\
\hline
\end{tabular}

Berdasarkan Tabel 7 bahwa terjadi peningkatan lagi dalam keterampilan sosial anak. Anak yang sangat aktif 19 anak (90,47\%) kategori sangat baik, 1 anak (4,76\%) kategori baik, 1 anak kategori cukup (4,76\%) dan sisanya o anak (o\%).

Tabel 8. Rekapitulasi Keseluruhan Keterampilan Sosial Anak Kondisi Awal, Siklus I, dan Siklus II

\begin{tabular}{clccc}
\hline No. & \multicolumn{1}{c}{ Indikator } & Kondisi awal & Siklus I & Siklus II \\
\hline 1. & Kerja sama & $3(14,28 \%)$ & $10(47,61 \%)$ & $19(90,47 \%)$ \\
2. & Persaingan baik & $3(14,28 \%)$ & $10(47,61 \%)$ & $19(90,47 \%)$ \\
3. & Kemurahan hati & $3(14,28 \%)$ & $10(47,61 \%)$ & $19(90,47 \%)$ \\
4. & Hasrat penerimaan sosial & $3(14,28 \%)$ & $10(47,61 \%)$ & $19(90,47 \%)$ \\
5. & Sikap ramah & $3(14,28 \%)$ & $10(47,61 \%)$ & $19(90,47 \%)$ \\
6. & Sikap tidak mementingkan sendiri & $3(14,28 \%)$ & $10(47,61 \%)$ & $19(90,47 \%)$ \\
\hline
\end{tabular}




\section{JPPM (Jurnal Pendidikan dan Pemberdayaan Masyarakat), 5 (1), 2018 - 93}

\section{S. Sudarto}

Dari data rekapitulasi hasil observasi keterampilan sosial pada Tabel 8, maka menunjukkan keterampilan sosial dari pratindakan sampai siklus II mengalami peningkatan secara signifikan.

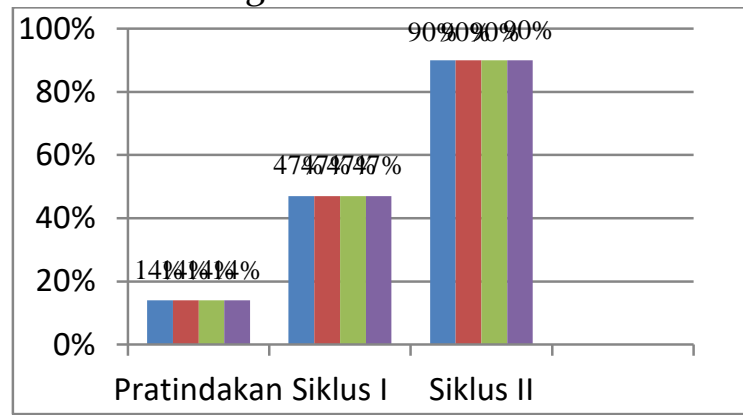

Gambar 1. Grafik Keterampilan Sosial Anak pada Kondisi Awal, Siklus I, dan Siklus II

\section{Pembahasan}

Hurlock (1978, p.26) mengatakan bahwa ada enam aspek utama dalam keterampilan sosial. Enam aspek penting tersebut adalah sebagai sebagai berikut: (1) Sikap ramah, (2) Sikap tidak mementingkan diri sendiri, (3) Kemurahan hati, (4) Hasrat akan penerimaan sosial, (5) Kerjasama, dan (6) Persaingan yang baik. Penelitian yang telah dilakukan adalah penelitian tindakan kelas (PTK). Siklus yang telah dilaksanakan terdiri dari siklus I dan siklus II masing-masing terdiri dari perencanaan, tindakan, pengamatan dan refleksi. Siklus II merupakan perbaikan dari siklus I secara keseluruhan keterampilan sosial anak mengalami peningkatan.

Pada pelaksanaan siklus I penelitian berjalan dengan lancar. Sebagian anak sudah mengetahui tentang permainan gobak sodor dan beberapa anak antusias mengikuti permainan gobak sodor. Sebelum memulai permainan guru membagi 2 kelompok yang masing-masing terdiri dari 5 anak laki-laki dan 5 anak perempuan. Kemudian 1 kelompok menunjuk 1 anak sebagai ketua dan dari masing-masing perwakilan atau ketua bersuit untuk menentukan sebagai penjaga dan penyerang. Dalam aturan permainan gobak sodor yang bertugas sebagai penjaga bilik bertugas untuk menghalang-halangi penyerang yang mau masuk ke dalam bilik, akan tetapi penjaga tidak boleh keluar garis. Tugas penyerang adalah berusaha berlari menghindari lawan tanpa disentuh lawan.
Berdasarkan hasil observasi pada siklus II, keterampilan sosial anak melalui permainan gobak sodor telah mengalami peningkatan sesuai dengan indikator keberhasilan. Pada keterampilan sosial, bekerjasama 19 anak (90,47\%), persaingan yang baik 19 anak (90,47\%), kemurahan hati 19 anak (90,47\%), hasrat akan penerimaan sosial 19 anak (90,47\%), sikap ramah (90,47\%), dan sikap tidak mementingkan diri sendiri (90,47\%).

Dari data yang diperoleh menunjukkan bahwa keterampilan sosial anak mengalami peningkatan yang signifikan melalui permainan tradisional gobak sodor. Hal ini juga sesuai dengan pendapat yang dikemukan oleh Parmadhi (2005, p.9) mengatakan bahwa permainan gobak sodor adalah permainan yang didasarkan kesepakatan bersama kawan-kawan dengan menentukan aturan putaran permainan.

Penelitian yang dilakukan oleh peneliti terdiri dari dua siklus. Siklus I dilaksanakan tiga kali pertemuan yaitu pada tanggal 28 Oktober sampai dengan tanggal 2 November 2015. Sedangkan siklus II dilaksanakan tiga kali pertemuan yaitu pada tanggal 4 November 2015 sampai dengan tanggal 9 November 2015. Berdasarkan hasil penelitian bahwa dari siklus I ke siklus II terjadi peningkatan yang signifikan keterampilan sosial siswa melalui permainan gobak sodor.

Sebelum diadakan permainan gobak sodor keterampilan sosial siswa belum meningkat. Setelah diadakan penelitian dalam permainan gobak sodor keterampilan sosial siswa meningkat dengan baik. Melihat peningkatan-peningkatan yang terjadi pada setiap pertemuan, peneliti dan guru kelas sangat senang dan puas hasil penelitian tindakan kelas terhadap anak kelompok B Taman Kanak-Kanak Panca Setya Kabupaten Sintang. Peneliti bersama guru kelas mengakhiri penelitian ini sampai dua siklus.

Pelaksanaan penelitian yang dilakukan di kelompok B TK Panca Setya Kabupaten Sintang masih terdapat beberapa keterbatasan, antara lain: (a) Penelitian ini hanya dilakukan pada anak kelompok B TK Panca Setya Kabupaten Sintang berjumlah 21 anak dan apabila penelitian ini dilakukan pada subjek yang berbeda, maka hasilnya akan berbeda pula, dan (b) Penelitian ini berfokus 
pada peningkatan keterampilan sosial melalui permainan gobak sodor dari aspek sikap ramah, sikap tidak mementingkan diri sendiri, kemurahan hati, hasrat akan penerimaan sosial, kerjasama, dan persaingan yang baik.

\section{SIMPULAN}

Berdasarkan hasil penelitian keterampilan sosial anak melalui permainan gobak sodor pada anak usia 5-6 tahun di TK Panca Setya Kabupaten Sintang adalah sebagai berikut: (1) proses peningkatan keterampilan sosial melalui permainan gobak sodor dengan melakukan pembagian tim secara seimbang dengan komposisi secara heterogen dan homogen baik anak laki-laki maupun perempuan. (2) melalui permainan gobak sodor pada anak usia 5-6 tahun di TK Panca Setya Kabupaten Sintang dapat meningkatkan keterampilan sosial anak. hal ini ditunjukkan dengan hasil peningkatan keterampilan sosial pratindakan bahwa dari 21 anak, tiga anak $(14,28 \%)$ pada kategori baik. Hasil siklus I keterampilan sosial anak meningkat menjadi 10 anak $(47,61 \%)$ pada kategori sangat baik. Hasil siklus I ke siklus II mengalami peningkatan keterampilan sosial pada kategori sangat baik menjadi 20 anak $(90,47 \%)$ pada kategori sangat baik.

Berdasarkan hasil penelitian, pembahasan dan simpulan yang diperoleh, maka implikasi sebagai berikut: (1) Proses peningkatan keterampilan sosial melalui permainan gobak sodor dengan melakukan pembagian tim secara seimbang dengan komposisi secara heterogen dan homogen baik laki-laki maupun perempuan, dan (2) melalui permainan gobak sodor pada anak usia 5-6 tahun di TK Panca Setya Kabupaten Sintang dapat meningkatkan keterampilan sosial anak. hal ini ditunjukkan dengan hasil peningkatan keterampilan sosial pratindakan bahwa dari 21 anak, 3 anak (14,28\%) pada kategori sangat baik. Hasil siklus I keterampilan sosial anak meningkat menjadi 10 anak $(47,61 \%)$ pada kategori sangat baik. Hasil siklus I ke siklus II mengalami peningkatan yang signifikan keterampilan sosial pada kategori sangat baik menjadi 20 anak (90,47\%).

\section{DAFTAR PUSTAKA}

Ahman. (1998). Efektifitas bermain peran sebagai model bimbingan dalam mengembangkan keterampilan sosial anak berkemampuan unggul. Jurnal penelitian, 3 (2)

Badegruber, B. (2008). 101 life skills games for children: Learning, growing, getting along (ages 6-12). Hunter House.

Bodrova, E., \& Leong, D. J. (2003). Chopsticks and counting chips: Do play and foundational skills need to compete for the teacher's attention in an early childhood classroom? Young Children, 58(3), 10-17.

Dowd, T. P., \& Tierney, J. (1992). Teaching social skills to youth: A curriculum for child-care providers. Boys Town, NE: Boys Town Press. Hurlock, E. B. (1978). Perkembangan anak. Erlangga.

Matson, J. L. (Ed.). (2009). Social behavior and skills in children. New York: Springer.

Lewis, G., \& Bedson, G. (2010). Games for children. Oxford University Press.

Liu, X. (2011). Young children's social skills development and academic achievement: Longitudinal analysis of developmental trajectories and environmental influences. State University of New York at Buffalo.

Lynch, S. A., \& Simpson, C. G. (2010). Social skills: Laying the foundation for success. Dimensions of Early Childhood, 38(2), 3-12.

Parmadhi, H. (2005). Bermain gobak sodor. Yogyakarta: Adicita Karya Nusa.

Plummer, D. (2007). Self-esteem games for children. Jessica Kingsley Publishers.

Koyama, T. (2011). The effects of social skills groups for young children with social delays (Doctoral dissertation). Retrived from http://hdl.handle.net/1773/17090

Kusumah, W., \& Dwitagama, D. (2011). Mengenal penelitian tindakan kelas. Edisi: 2. Jakarta : PT Indeks.

Spence, S. H. (2003). Social skills training with children and young people: Theory, evidence and practice. Child 
JPPM (Jurnal Pendidikan dan Pemberdayaan Masyarakat), 5 (1), 2018 - 95

S. Sudarto

and adolescent mental health, 8(2), 8496.

Wahyuningsih, D., \& Suyanto, S. (2015). Implementasi kearifan lokal melalui model bcct untuk pengembangan kemampuan sosial anak usia dini. JPPM (Jurnal Pendidikan dan Pemberdayaan Masyarakat), 10-23. doi:http://dx.doi.org/10.21831/jppm.v2i 1.4840

Wike, T. L. (2011). The effectiveness of a social skills intervention for preventing aggression in children: an evaluation of the making choices intervention. Disertation. University of North Carolina 